\title{
Reaction of Indonesian Capital Market Investors to the Implementation of Tax Amnesty
}

\author{
Agung Wibowo ${ }^{1}$, Susetyo Darmanto ${ }^{2}$ \\ ${ }^{1}$ Department of Accounting Faculty of Economics and Business University of 17 Agustus 1945 Semarang \\ ${ }^{2}$ Department of Management Faculty of Economics and Business University of 17 Agustus 1945 Semarang \\ Jl. Pawiyatan Luhur Bendan Dhuwur, Semarang 50235
}

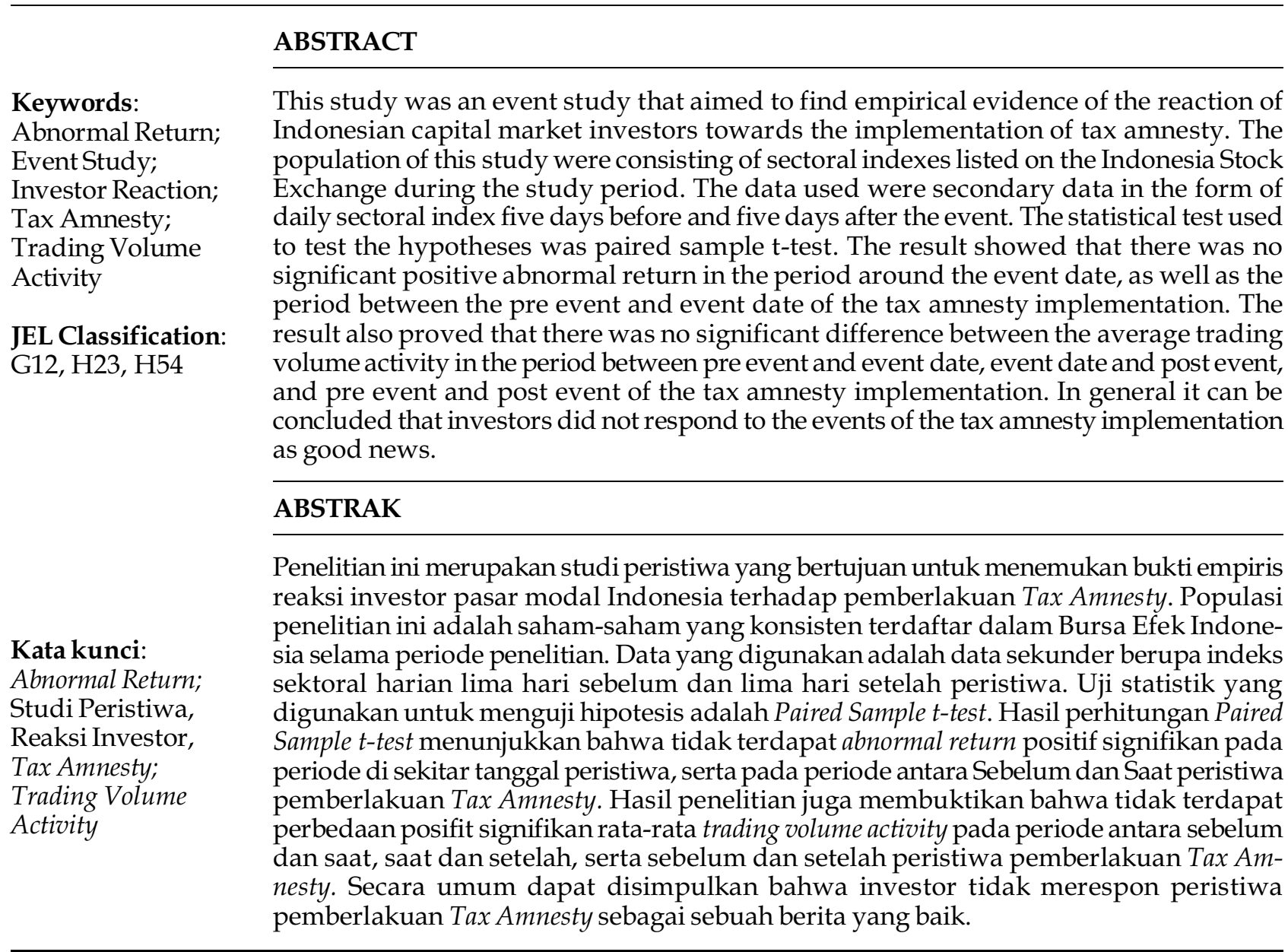




\section{Jurnal Keuangan dan Perbankan | KEUANGAN}

Vol. 21, No. 4, Oktober 2017: 597-608

The capital market, as one of the economic instruments of a country, is heavily influenced by events. These events can come from internal companies (issuers) and external companies. Events that come from internal company is a micro event, so it will only affect the fluctuation of price and volume of trading company shares, while events from external company is a macro event, so that will affect the fluctuations in price and volume of trading stock companies all sectors in the capital market. The fluctuations in price and volume of stock trading of companies in all sectors in the capital market will be reflected in fluctuations in stock price index and trading volume. An event will affect the stock price and volume of trade if the event by investors is seen as a relevant event, so it has information content. This information is very important in order to obtain a description of risk and expected return in order to form an optimal portfolio. One of the macro events, which are deemed to contain information relevant to investors is the implementation of tax amnesty.

The implementation of the tax amnesty policy is an interesting event to examine its impact on the Indonesian capital market because it is issued in the middle of the sluggish world economy, where the continuing issue of US central bank interest rate increases, tappering off, as well as low world oil prices, which in November 2016 was still at the level of US\$ 50.15. Several event studies that have been conducted to analyze the reaction of Indonesian capital market investors to domestic economic events have proven that these events have relevant information content for capital market investors, so that capital market investors react, for example in the event of liquidation 16 Bank 1997 (Manullang, 2004). However, in several other study events on domestic economic events, proving that there is no information content, so that capital market investors do not react, for example in the event of fuel price hike on April 1, 2002 and the event of BI's endorsement on May 14, 2003
(Manullang, 2004). Several studies that contradict this result indicate that not all domestic economic events have information content, so the question arises whether the event of the implementation of tax amnesty has information content for Indonesia capital market investors?

This study is intended to find empirical evidence in a way that is different from previous researches. According Jogiyanto (2015), an event may affect only a particular company, affect a particular sector, or affect all sectors in the capital market. Implementation of tax amnesty is an event affecting all sectors in the capital market, therefore in this study is analyzed in aggregate, so abnormal return used is the abnormal return of sectoral index. This study is intended to find empirical evidence in a way that is different from previous research. According Hartono (2008), an event may affect only a particular company, affect a particular sector, or affect all sectors in the capital market. Implementation of tax amnesty is an event affecting all sectors in the capital market, therefore in this study is analyzed in aggregate, so abnormal return used is the abnormal return of sectoral index.

\section{HYPOTHESES DEVELOPMENT}

Trading volume activity is the sales volume of any transactions that occure on the stock market at any given moment and on certain shares. Trading volume activity is one factor that gives effect to stock price movement. Trading volume is a key element in predicting stock price movements. Trading volume is seen as an important part of the information that gives the signal of the next price movement where the stock price can not be delivered to the market players (Mahajan \& Singh, 2008). Some studies have proven the linkage between trading volume and stock prices (Kim \& Verecchia, 1991; Brailsford, 1996; Smirlock \& Starks, 1988; and Mahajan \& Singh, 2008). 
The relationship of stock price and trading volume can be used as the basis of trading strategy and as evidence of the efficiency of the stock market (Mahajan \& Singh, 2008) and (Admati \& Pfleidere, 1988).

Trading volume can be composed into two components: number of trades and the average size of trades (Gopinath \& Krishnamurti, 2001). Number of transactions is the number of individual transactions for a given number of shares and trade size is defined as the total number of shares traded in a period (day) divided by the number of transactions (Chan \& Fong, 2000) or the average volume of shares per transaction (Sukamulja, 2002). Gopinath \& Krishnamurti (2001) state that the number of transactions contains more information than trading volumes. Gopinath \& Krishnamurti (2001), Sukamulja (2002), and Izzeldin (2007) found significant influence between number of transactions and stock price volatility. Study by Izzeldin (2007) proves that number of trades is the best proxy for explaining market activity rather than volume. Study by Xu \& Wu (1999) found that the number of transactions and trade sizes significantly affected return volatility. Xu \& Wu (1999) also found the effect of number of transactions stronger than the trade size on intraday intervals. Based on above mention information, the research model can be described as follows.

Based on the explanation and research model, the hypotheses proposed as follows.

$\mathrm{H}_{1 \mathrm{a}}$ : There is a positive and significant of Abnormal Return (AR) around the date of implementation of the tax amnesty.

$\mathrm{H}_{1 \mathrm{~b}}$ : There is a positive and significant of Abnormal Trading Volume Activity (ATVA) around the date of the implementation of the tax amnesty.

$\mathrm{H}_{2 \mathrm{a}}$ : There is an significant average difference in average Abnormal Return (AR) of stocks between the period pre event and event date of the implementation of the tax amnesty.

$\mathrm{H}_{2 \mathrm{~b}}$ : There is a significant difference in Trading Volume Activity (TVA) of stocks between the period pre event and event date of the implementation of tax amnesty.

$\mathrm{H}_{3 \mathrm{a}}$ : There is a significant average difference in average Abnormal Return (AR) of stocks that is statistically significant between the period

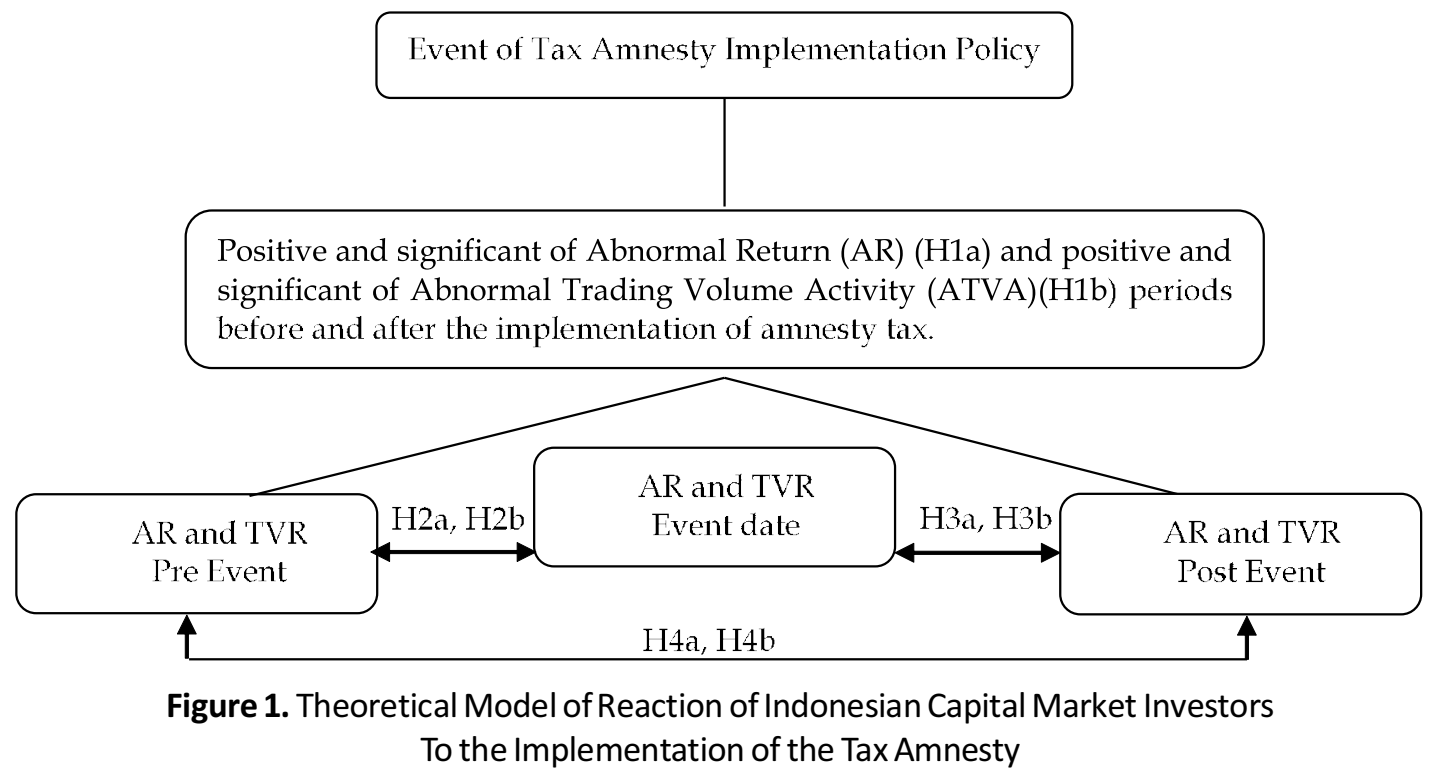


event date and post event of the implementation of tax amnesty.

$\mathrm{H}_{3 \mathrm{~b}}$ : There is a significant difference in Trading Volume Activity (TVA) of stocks between the event date and post event periods of tax amnesty.

$\mathrm{H}_{4 \mathrm{a}}$ : There is a statistically significant difference in average Abnormal Return (AR) of stocks between the pre event and post event periods of the implementation of tax amnesty.

$\mathrm{H}_{4 \mathrm{~b}}$ : There is a significant difference in Trading Volume Activity (TVA) of stocks between the pre event and post event periods of the implementation of the tax amnesty.

\section{METHODS}

The population of this research are sectoral indexes in Indonesian Stock Exchange (IDX) in November 2016 as much as 10 sectors index. This research is a census study because it uses all sectoral indices listed in IDX, so the unit of analysis of this research is which is proxy with sector index, so the unit of analysis of this research is sector index on IDX. The reason for choosing all sectoral indexes as the unit of analysis of this re- search is based on the consideration that the implementation of tax amnesty policy is a macro policy, affecting all companies listed on the IDX, and the impact is not only for a moment, so that in analyzing the impact must be done aggregate by using sectoral index.

The date of an event published for the first time is set as event day - $t 0$. If the date is a holiday date for stock trading, the nearest trading date of the next stock is designated as an event day. The event period used in this research are five trading days prior to the occurrence of $(t-5)$ to five trading days after the occurrence of events $(t+5)$. With 11-day event period, IDX investors' reaction to the implementation of Tax Amnesty policy can be seen. Meanwhile, according to Affandi \& Utama (1998), when the event period used is too long, it is feared there are other events that also cause the reaction of investors, so that the results of research into bias. In order to obtain the expected return during the period of the event, a 30-day period of estimation is required, i.e. from 6 trading days before the occurrence ( $\mathrm{t}-6)$ up to 35 trading days before the event $(t-35)$. This 30-day period of estimate is considered sufficient to predict the expected return during the event period.

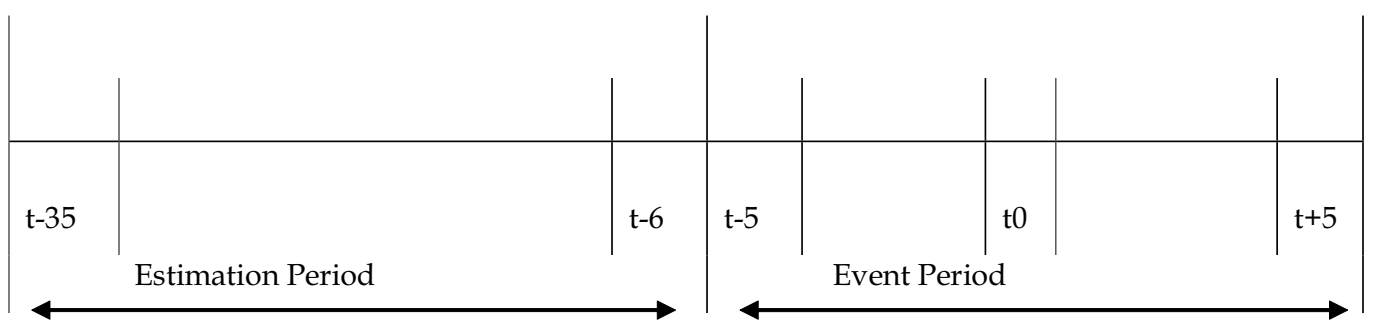

Event period and estimation period for each event described in below table.

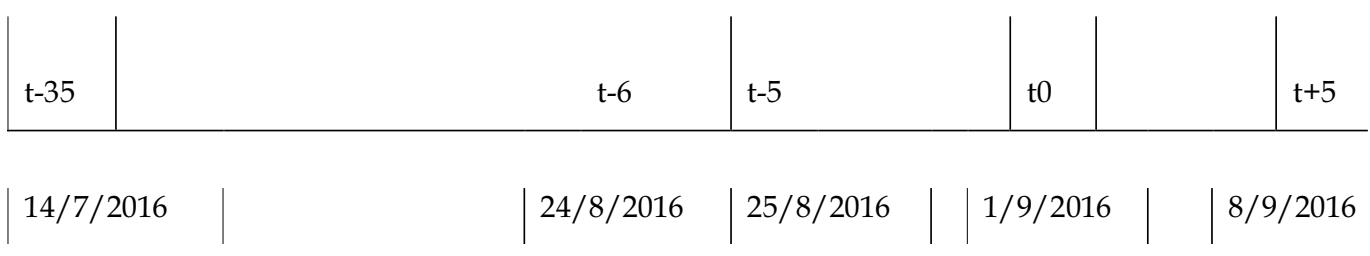

Figure 2. Period of Research 
The variables of this research are investor reaction measured by using AR and TVA. Abnormal return is defined as the difference between the actual profit level and the expected return. Mathematically abnormal return is formulated as follows:

ARi, $\mathrm{t}$ : abnormal return of sector $\mathrm{i}$ on day $\mathrm{t}$.

$\mathrm{Ri}, \mathrm{t} \quad$ : actual return of sector $\mathrm{i}$ on day $\mathrm{t}$.

E (Ri) : expected return sector $i$.

Actual return of sector $\mathrm{i}$ on day $\mathrm{t}$, can be calculated by the formula:

$\mathrm{Ri} \quad$ : actual sector return $\mathrm{i}$ on day $\mathrm{t}$.

$\mathrm{Pi}, \mathrm{t} \quad$ : sector index $\mathrm{i}$ on day $\mathrm{t}$.

$\mathrm{Pi}, \mathrm{t}-1 \quad$ : index of sector $\mathrm{i}$ on day $\mathrm{t}-1$.

In this study, the expected return is calculated using the Mean-adjusted Model with the equation:

E (Ri) : expected return sector i during the event period.

$\Sigma \mathrm{Ri} \quad$ : total sectoral return i.

n : number of records of sector i returns during period $\mathrm{t}-6$ to $\mathrm{t}-35$.

Gopinant \& Krishnamurti (2001) stated that the number of transactions/trading frequencies contain more information than trading volumes. Therefore TVA in this study is measured using the trading frequency. While abnormal trading volume activity (ATVA) is mathematically formulated as follows.

ATVAi, $\mathrm{t}$ : abnormal trading volume activity sector $\mathrm{i}$ on day $\mathrm{t}$.

TVAi, $\mathrm{t} \quad$ : trading volume activity sector $\mathrm{i}$ on day t.

E (Ri) : expected trading volume activity sector i.
Hypotheses testing of significant positive abnormal return (H1a) and significant abnormal trading volume activity (ATVA) (H2a) in the period of the implementation of tax amnesty policy is used one sample t-test where the null hypotheses is flat abnormal return and average abnormal trading volume activity on day $t$ is zero.

If the significance value of one sample $t$ test is smaller than 0.05 , then the null hypotheses is rejected or receives $\mathrm{H} 1 \mathrm{a}$ and $\mathrm{H} 2 \mathrm{a}$, meaning that Indonesia Stock Exchange (IDX) investors react to the tax amnesty policy. Hypotheses testing of significant positive abnormal return (H1a) and significant abnormal trading volume activity (ATVA) (H2a) in the period of tax amnesty policy implementation is used One Sample t-test where the null hypotheses is flat abnormal return and average abnormal trading volume activity on day $t$ is zero. If the significance value of One Sample $t$ - test is smaller than $=0.05$, then the null hypotheses is rejected or the IDX investors reacts to the tax amnesty policy. Hypotheses testing of the difference of mean abnormal return of significant between pre event and event date (H2a) and the difference of mean trading volume activity significant between pre event and event date $(\mathrm{H} 2 \mathrm{~b})$, between event date and post event (H3a) and (H3b), between pre event and post event (H4a) and (H4b) the tax amnesty implementation is used by the mean difference test of Paired Sample t-test, where the null hypotheses is the average difference of abnormal return and trading volume activity between pre event and event date and post event, between pre event and post event the implementation of tax amnesty is zero. If the significance value of the Paired Sample T-test is smaller than 0.05

Testing using Paired Sample T-test requires data to be normally distributed so that if the data is not normally distributed it will be used Wilcoxon test, the basis of withdrawal is if $\mathrm{p}$-value Wilcoxon test statistic $<0,05$ then null hypotheses rejected or accept Ha. 


\section{Jurnal Keuangan dan Perbankan | KEUANGAN}

Vol. 21, No. 4, Oktober 2017: 597-608

This study uses secondary data collected from the official website of Indonesia Stock Exchange (www.idx.co.id). The data collected are: (1) the date of the inception of tax amnesty policy is obtained from Indonesia Stock Exchange (www.idx.co.id). (2) Sectoral indices are obtained from the official website of Indonesia Stock Exchange (www.idx.co.id). (3) Number of sectoral shares traded on day $t$ is obtained from the official website of Indonesia Stock Exchange (www.idx.co.id). (4) Number of sectoral shares outstanding on day $t$ is obtained from the official website of Indonesia Stock Exchange (www.idx.co.id).

\section{RESULTS}

The calculation result of descriptive statistic of overall abnormal return of sectoral index during the study period is presented in the following Table 2.

Based on Table 2, it is known that for five days prior to the tax amnesty event, the average of overall abnormal return index is negative, and at the time of tax amnesty, the average of overall abnormal return index is also negative, indicating that both five days prior to the time of the tax amnesty implementation there is no reaction from the investors. New investors reacted after the tax amnesty event, as indicated by the average of overall sectoral overall abnormal return indexes are positive, but the value is so small that it needs to be tested for significance.

The average abnormal return calculation of all sectoral index on a daily basis during the period of the announcement of the tax amnesty implementation can be seen in Table 3 . The average abnormal return calculation results of all sector indices during the five days prior to event $(\mathrm{t}-$ $5)$ up to the time of occurrence event (t0) shows the values that vary between positive and negative, this indicates that in the period t- 5 to to the stock exchange is still running normally or there has been no reaction from the investor to the tax amnesty implementation. In the period $t+1$ to $t+$ 3 there is a positive abnormal return, this indicates that investors start reacting to the event of the announcement of tax amnesty, but the average abnormal return in the period $t+1$ to $t+3$ value is so small that it is necessary tested its significance. While at $t+4$ up to $t+5$ the abnormal return is negative, this indicates that investor's reaction to the event of tax amnesty is gone, and the stock returns to normal.

Tabel 2. Average Abnormal Return (AAR), Standard Deviation (SD) and Average of Overall Abnormal Return Sectoral Index during Periode of the Event

\begin{tabular}{lcccrr}
\hline & Five Days Before the Event & At the EventDate & \multicolumn{2}{c}{$\begin{array}{c}\text { Five Days Before } \\
\text { the Days }\end{array}$} \\
\hline Agriculture & AAR & SD & AAR & AAR & SD \\
Mining & -0.004 & 0.014 & -0.017 & 0.000 & 0.003 \\
Basic-Industry & -0.003 & 0.013 & -0.004 & 0.008 & 0.012 \\
Misc-Industry & -0.004 & 0.009 & -0.016 & -0.003 & 0.008 \\
Consumer & -0.006 & 0.018 & -0.019 & 0.002 & 0.008 \\
Property & 0.000 & 0.011 & -0.007 & -0.002 & 0.008 \\
Infrastructure & -0.006 & 0.010 & -0.017 & -0.004 & 0.008 \\
Finance & -0.003 & 0.011 & -0.017 & -0.001 & 0.006 \\
Trade & -0.005 & 0.007 & -0.011 & 0.001 & 0.004 \\
Manufacture & 0.001 & 0.006 & -0.010 & -0.001 & 0.003 \\
Average of Overall & -0.001 & 0.011 & -0.010 & $\mathbf{0 . 0 0 1}$ & $\mathbf{0 . 0 0 3}$ \\
\hline
\end{tabular}


Hypotheses testing (H1a) stated that there was a positive and significant of AR around the date of the tax amnesty enforcement event.

The result of the test of positive abnormal return which is statistically significant around the occurrence of tax amnesty (H1a) is presented in Table 4 . From Table 4 it can be seen that in period $\mathrm{t}-4, \mathrm{t}-3$, and $\mathrm{t} 0$ indicates significance $<0.05$ but the mean abnormal returns are marked negative, while in other periods it indicates significance $>0.05$, so it can be concluded that there is no significant abnormal return around the implementation of tax amnesty or H1a is rejected.

Hypotheses testing $(\mathrm{H} 1 \mathrm{~b})$ stated that there was a positive and significant of Abnormal Trading Volume Activity (ATVA) around the date of the amnesty tax enforcement event.

Table 3. Average of Abnormal Return during Periode of the Event

\begin{tabular}{cccl}
\hline Periode & Date & $\begin{array}{c}\text { Average Abnormal } \\
\text { Return }\end{array}$ & Explanation \\
\hline $\mathrm{t}-5$ & $25 / 08 / 2016$ & 0.006 & \\
$\mathrm{t}-4$ & $26 / 08 / 2016$ & -0.006 & Abnormal return has positive and negative signs which \\
$\mathrm{t}-3$ & $29 / 08 / 2016$ & -0.017 & suggested no reaction from the investors yet \\
$\mathrm{t}-2$ & $30 / 08 / 2016$ & -0.003 & \\
$\mathrm{t}-1$ & $31 / 08 / 2016$ & 0.003 & Abnormal return has positive signs which suggested \\
$\mathrm{t} 0$ & $01 / 09 / 2016$ & -0.013 & there is a reaction form the investors \\
$\mathrm{t}+1$ & $02 / 09 / 2016$ & 0.002 & Abnormal return has negative signs which suggested \\
$\mathrm{t}+2$ & $05 / 09 / 2016$ & 0.003 & there is no reaction from the investors \\
$\mathrm{t}+3$ & $06 / 09 / 2016$ & 0.000 &
\end{tabular}

Table 4. Result Abnormal Return test at the Periode of the Event

\begin{tabular}{|c|c|c|c|}
\hline Period & $\begin{array}{c}\text { Average of Abnormal } \\
\text { Return }\end{array}$ & Significance & Explanation \\
\hline $\mathrm{t}-5$ & 0.0055 & 0.096 & $\begin{array}{l}\text { Not significant } \\
\text { Not significant }\end{array}$ \\
\hline $\mathrm{t}-4$ & -0.0056 & 0.013 & $\begin{array}{l}\text { Abnormal Return has negative sign which suggested } \\
\text { there is no reaction from the investor }\end{array}$ \\
\hline $\mathrm{t}-3$ & -0.0168 & 0.000 & $\begin{array}{l}\text { Not significant } \\
\text { Abnormal Return has negative sign which suggested } \\
\text { there is no reaction from the investor }\end{array}$ \\
\hline $\mathrm{t}-2$ & -0.0030 & 0.216 & Not significant \\
\hline $\mathrm{t}-1$ & 0.0033 & 0.051 & $\begin{array}{l}\text { Not significant } \\
\text { Not significant }\end{array}$ \\
\hline $\mathrm{t}-0$ & -0.0128 & 0.000 & $\begin{array}{l}\text { Abnormal Return has negative sign which suggested } \\
\text { there is no reaction from the investor }\end{array}$ \\
\hline$t+1$ & 0.0017 & 0.272 & Not significant \\
\hline$t+2$ & 0.0028 & 0.445 & Not significant \\
\hline$t+3$ & 0.0000 & 1.000 & Not significant \\
\hline$t+4$ & -0.0017 & 0.403 & Not significant \\
\hline$t+5$ & -0.0031 & 0.114 & Not significant \\
\hline
\end{tabular}




\section{Jurnal Keuangan dan Perbankan | KEUANGAN}

Vol. 21, No. 4, Oktober 2017: 597-608

Test results of abnormal trading volume activity positive statistically significant around the occurrence of tax amnesty (H1b) is presented in Table 5. From Table 5 it can be seen that in period $\mathrm{t}-4, \mathrm{t}-3$, and $\mathrm{t}+1$ showed significance $<0,05$ but the average of abnormal trading volume activity is negative, while in other periods it indicates significance $>0,05$, so it can be concluded that there is no abnormal trading volume activity positive statistically significant around the implementation of tax amnesty or H1b is rejected.
Hypotheses testing ( $\mathrm{H} 2 \mathrm{a})$ stated that there was a difference in average AR is statistically significant between the period pre event and event date of the implementation of tax amnesty. The test of average difference of abnormal return between the period pre event and event date of tax amnesty (H2a) implementation is used paired samples T-test which results are presented in Table 6.

Based on Table 6, it can be seen that the result between the pre event and event date of the occurrence of tax amnesty implementation is $<0,05$

Tabel 5. Result of Abnormal Trading Volume Activity (ATVA) Test the Period of the Event Date

\begin{tabular}{|c|c|c|c|}
\hline Period & $\begin{array}{c}\text { Average } \\
\text { of Abnormal TVA }\end{array}$ & Significance & Explanation \\
\hline$t-5$ & $1,559.900$ & 0.528 & $\begin{array}{l}\text { Not significant } \\
\text { Not significant }\end{array}$ \\
\hline $\mathrm{t}-4$ & $-6,857.100$ & 0.009 & $\begin{array}{l}\text { Average of Abnormal TVA has negative sign which } \\
\text { suggested there is no reaction from investor } \\
\text { Not significant }\end{array}$ \\
\hline$t-3$ & $-5,080.100$ & 0,008 & $\begin{array}{l}\text { Average of Abnormal TVA has negative sign which } \\
\text { suggested there is no reaction from investor }\end{array}$ \\
\hline $\mathrm{t}-2$ & $-2,434.700$ & 0.221 & Not significant \\
\hline$t-1$ & $1,026.400$ & 0.611 & Not significant \\
\hline t0 & -203.200 & 0.118 & $\begin{array}{l}\text { Not significant } \\
\text { Not significant }\end{array}$ \\
\hline$t+1$ & $-7,626.600$ & 0.002 & $\begin{array}{l}\text { Average of Abnormal TVA has negative sign which } \\
\text { suggested there is no reaction from investor } \\
\text { Not significant }\end{array}$ \\
\hline$t+2$ & $-7,921.200$ & 0.012 & $\begin{array}{l}\text { Average of Abnormal TVA has negative sign which } \\
\text { suggested there is no reaction from investor }\end{array}$ \\
\hline$t+3$ & $-4,565.300$ & 0.163 & Not significant \\
\hline$t+4$ & $-1,484.400$ & 0.582 & Not significant \\
\hline$t+5$ & $-2,147.500$ & 0.505 & Not significant \\
\hline
\end{tabular}

Table 6. Result of Difference test of Abnormal Return Pre Event and Event Date of the Implementation of Tax Amnesty

\begin{tabular}{lcccc}
\hline & Event & $\begin{array}{c}\text { Difference of } \\
\text { Abnormal Return Average }\end{array}$ & $\begin{array}{c}\text { Standard } \\
\text { Deviation }\end{array}$ & Sig. (2-tailed) \\
\hline Pair 1 & Event Date -Pre Event & -0.00970 & 0.00403 & 0.000 \\
\hline
\end{tabular}

Tabel 7. Result of Difference Trading Volume Activity (TVA) Test Pre Event and Event Date the Occurrence of Tax Amnesty Implementation

\begin{tabular}{ccccc}
\hline Event & $\begin{array}{c}\text { Difference of } \\
\text { Average Abnormal Return }\end{array}$ & $\begin{array}{c}\text { Standard } \\
\text { Deviation }\end{array}$ & Sig. (2-tailed) \\
\hline Pair 1 & Pre Event - Event Date & 0.013500 & 0.005212 & 0.000 \\
\hline
\end{tabular}


which is statistically significant, so it can be concluded that $\mathrm{H} 2 \mathrm{a}$ accepted

Hypotheses testing $(\mathrm{H} 2 \mathrm{~b})$ that there was a difference in average trading volume activity (TVA) of stocks that are statistically significant between the period pre event and event date of the implementation of tax amnesty.

The test of difference of mean trading volume (TVA) between period of pre event and event date of tax amnesty (H2b) implementation is used paired samples t- test which result is presented in Table 7.

Based on Table 7 it can be seen that the result between the pre event and event date of the occurrence of the amnesty tax implementation there is $>0,05$ which is statistically not significant, so it can be concluded that $\mathrm{H} 2 \mathrm{~b}$ rejected or no reaction Indonesian capital market investors against the implementation of tax amnesty.
Hypotheses testing ( $\mathrm{H3a}$ ) stated that there was a difference in average abnormal return (AR) of stocks that are statistically significant between the period of event date and post event of the occurrence of tax amnesty. Testing the average difference of abnormal return between the period of event date and post event the occurrence of tax amnesty (H3a) used paired samples t-test which results are presented in Table 8 .

Based on Table 8, it can be seen that between the event date and post event of the occurrence of the amnesty tax implementation there is an increase in the average abnormal return of 0.013500 which is statistically significant so it can be concluded that $\mathrm{H3a}$ is accepted, but this result must be confirmed through testing TVA to ascertain whether the average increase of abnormal return is real or only false that does not reflect the reaction of Indonesian capital market investors to the tax amnesty event.

Tabel 8. Result of the Difference Abnormal Return Test Pre Event and Event Date (H3a) of the Implementation of Tax Amnesty

\begin{tabular}{ccccc}
\hline Event & $\begin{array}{c}\text { Difference of } \\
\text { Average Abnormal Return }\end{array}$ & $\begin{array}{c}\text { Standard } \\
\text { Deviation }\end{array}$ & Sig. (2-tailed) \\
\hline Pair 1 & Pre Event - Event Date & 0.013500 & 0.005212 & 0.000 \\
\hline
\end{tabular}

Tabel 9. Result of Difference Trading Volume Activity (TVA) Test Event Date and Post Event (H3b) the occurrence of the Event of the Implementation of Tax Amnesty

\begin{tabular}{lcccc}
\hline & Event & $\begin{array}{c}\text { Difference of } \\
\text { Average TVA }\end{array}$ & Standard Deviation & Sig. (2-tailed) \\
\hline Pair 1 & TVA Pre Event - TVA Event Date & -547.800 & 2966.862 & 0.574 \\
\hline
\end{tabular}

Tabel 10. Result of Difference Abnormal Return Before and After ( $\mathrm{H} 4 \mathrm{a})$ the Occurrence of the Event of the Implementation of Tax Amnesty

\begin{tabular}{ccccc}
\hline Event & $\begin{array}{c}\text { DifferenceAverage } \\
\text { Abnormal Return }\end{array}$ & Standard Deviation & Sig. (2-tailed) \\
\hline Pair 1 & Post Event - Pre Event & 0.003800 & 0.00492 & 0.02500 \\
\hline
\end{tabular}

Table 11. Result of the Difference of Trading Volume Activity (TVA) Test Pre Event and Post Event of the Implementation of Tax Amnesty

\begin{tabular}{ccccc}
\hline Event & $\begin{array}{c}\text { Difference } \\
\text { Average TVA }\end{array}$ & $\begin{array}{c}\text { Standar } \\
\text { Deviation }\end{array}$ & Sig. (2-tailed) \\
\hline Pair 1 & TVA Post Event - TVA Pre Event & -1983.200 & 3533.68290 & 0.1100 \\
\hline
\end{tabular}




\section{Jurnal Keuangan dan Perbankan | KEUANGAN}

Vol. 21, No. 4, Oktober 2017: 597-608

Hypotheses testing $(\mathrm{H} 3 \mathrm{~b})$ stated that there was a difference in average trading volume activity (TVA) of stocks that are statistically significant between the period of event date and post event of the occurrence of tax amnesty.

Testing the difference in the TVA between the Event date and post event periods of the implementation of tax amnesty ( $\mathrm{H} 3 \mathrm{~b})$ is used paired samples t-test which results are presented in Table 9.

Based on Table 9, it can be seen that between the event date and post event the occurrence of the tax amnesty implementation there is a decrease in average TVA of -547.800 which is not statistically significant so it can be concluded that $\mathrm{H} 3 \mathrm{~b}$ rejected or no reaction of Indonesian capital market investors to events the imposition of tax amnesty. The result of $\mathrm{H} 3 \mathrm{~b}$ test confirms the result of H3a test that the average increase of abnormal return between the event date and post event the tax amnesty implementation is only pseudo that does not reflect the reaction of Indonesian capital market investors to the tax amnesty implementation.

Hypotheses testing H4a stated that there was a difference in average AR stocks are statistically significant between the period pre event and post event the implementation of tax amnesty. Testing the average difference of abnormal return between the period before and after the implementation of tax amnesty (H4a) used paired samples t-test which results are presented in Table 10.

Based on Table 10 it can be seen that between Before and After the occurrence of Amnesty tax enforcement event there is an increase of abnormal return average of 0.003800 which is statistically significant so it can be concluded that $\mathrm{H} 4 \mathrm{a}$ is accepted, but this result must be confirmed through testing using TVA to ascertain whether the average increase of abnormal return is real or only pseudo that does not reflect the reaction of
Indonesian capital market investors to the event of tax amnesty.

Hypotheses testing $\mathrm{H} 4 \mathrm{~b}$ stated that there was a difference in average TVA that are statistically significant between the period pre event and post event implementation of tax amnesty. The test of average difference of TVA between pre event and post event period of tax amnesty (H3b) implementation is used paired samples t-test which results are presented in Table 11.

Based on Table 11, it can be seen that between pre event and post event the occurrence implementation of tax amnesty there is a decrease in average TVA of $-1983,200$ which is not statistically significant so it can be concluded that $\mathrm{H} 4 \mathrm{~b}$ rejected or no reaction Indonesian capital market investors against the implementation of tax amnesty.

\section{DISCUSSION}

The result shows that there is no significant Abnormal Return (AR) and abnormal trading volume activity (ATVA) around the occurrence of tax amnesty event, this indicates that Indonesian capital market investors do not react around the date of the tax amnesty event.

The result shows that between the pre event and event date of the occurrence of tax amnesty implementation is significant (accepted), but there is a decrease in average abnormal return of -0.00970 which is concluded that no reaction of Indonesian capital market investors to the implementation of tax amnesty.

The results show that there is a decrease in abnormal return and the average TVA between the pre event and event date the occurrence of the amnesty tax implementation, this indicates that there is no reaction of Indonesia capital market investors between the pre event and event date of the tax amnesty implementation. 
The results show that between the event date and post event the occurrence of the tax amnesty implementation there is an increase in average abnormal return, but on the other hand it actually decreased the average TVA, so it can be concluded that there is no reaction of Indonesian capital market investors to the implementation of tax amnesty.

The results show that between the pre event and post event the occurrence of tax amnesty implementation, there is an increase in average abnormal return, but on the other hand there is a decrease in average TVA, so that does not reflect the reaction of Indonesian capital market investors to the event of the implementation of tax amnesty because it is not accompanied by the increase of transaction.

The findings supported some previous studies. The study of Rokhman, Didied, \& Kiptiyah (2009) found significant abnormal return pre event and event date at the period of stock split announcement of manufacture companies at IDX. The result study of Haryanto (2011) concluded that investors did not react to information cash dividends at Indonesia Stock Exchange. Study of Mahaputra \& Purbawangsa (2015) found no significant effect of the abnormal return at pre event and post event of parliamentary election in 2014. Pratama, Sinarwati, \& Darmawan (2015) also did not find significant effect of the abnormal return before and after the inauguration of Presiden Joko Widodo. Study of Bhavani \& Kukunuru (2016) didn't find overreaction of Dubai Financial Market stocks with regard to the event of Dubai Financial Market. Gunarsih \& Perwitasari (2017) also found no reaction before and after the release of regulation in TVA to the changing of capital markets tick size regulation in May 2nd, 2016.

Based the test result of all hypotheses shows that there is no positively reaction of Indonesian capital market investor to the implementation of tax amnesty, this happened for two reasons, namely: first, that tax amnesty is a government policy aimed at attracting Indonesian citizens who are kept abroad, so as not to directly affect the Indonesian capital market. Second, the tax amnesty policy is a long term policy whose impact will be felt in the next few years (Said, 2017), so that investors do not directly respond to the implementation of the tax amnesty

\section{CONCLUSION AND SUGGESTION}

\section{Conclusion}

The results of research show that around the event date of the implementation of tax amnesty and between pre event and event date of the implementation of tax amnesty there is a decrease in abnormal return and the average volume of trading activity (TVA), which indicates that Indonesia capital market investors do not react positively to tax amnesty events. The result of research also shows that there is an average increase of abnormal return between event date and post event the implementation of tax amnesty and pre event and post event the implementation of tax amnesty, but on the other hand there is decrease of activity of average trade volume (TVA), it shows that the increase of abnormal return is only pseudo, because it is not accompanied by an increase in the volume of trading activity, so it can be concluded that there is no reaction of Indonesian capital market investors to the occurrence of tax amnesty.

\section{Suggestions}

This research uses a mean-adjusted model, in estimating expected rate of return. Therefore, for further research it is advisable to try to use market adjusted model and market model or use the three models, then the results of the calculations of the three models can be compared to know the impact on the research results.

This research uses only one indicator of market reaction measure, i.e abnormal return and 


\section{Jurnal Keuangan dan Perbankan | KEUANGAN}

Vol. 21, No. 4, Oktober 2017: 597-608

trading volume activity as measured by the frequency of trade, therefore for further research it is suggested to develop other indicators of market reaction measure such as stock trading volume and bid- ask spread spreads to enrich the results of the research

\section{REFERENCES}

Admati, A. R., \& Pfleiderer, P. (1988). A theory of intraday patterns: Volume and price variability. The Review of Financial Studies, 1(1), 3-40.

Affandi, U., \& Utama, S. (1998). Uji efisiensi bentuk setengah kuat pada Bursa Efek Jakarta. Manajemen Usahawan Indonesia.

Bhavani, G., \& Kukunuru, S. G. (2016). Impact of EXPO 2020 on Dubai Financial Market-An event study on banks, investment and insurance sectors. International Journal of Financial Research, 7(2), 163.

Chan, K., \& Fong, W.-M. (2000). Trade size, order imbalance, and the volatility-volume relation. Journal of Financial Economics, 57(2), 247-273.

Gopinath, S., \& Krishnamurti, C. (2001). Number of transactions and volatility: an empirical study using high frequency data from Nasdaq stocks. Journal of Financial Research, 24(2), 205-218.

Gunarsih, T., \& Perwitasari, A. W. (2017). TVA, abnormal return, and investor perception on changing of tick size 2 May 2016. Jurnal Keuangan dan Perbankan, 21(3), 366-375.

Hartono, J. (2008). Teori portofolio dan analisis investasi. Edisi Kelima. Yogyakarta: BPFE.

Haryanto, S. (2011). Reaksi investor terhadap pengumuman dividen di Bursa Efek Indonesia. Jurnal Keuangan dan Perbankan, 15(2), 213-220.
Izzeldin, M. (2007). Trading volume and the number of trades: a comparative study using high frequency data.

Mahajan, S., \& Singh, B. (2008). An empirical analysis of stock price-volume relationship in Indian stock market. Vision, 12(3), 1-13.

Mahaputra, I., \& Purbawangsa, I. B. A. (2015). Pengaruh peristiwa Pemilu legislatif 2014 terhadap perolehan abnormal return saham LQ 45 di Bursa Efek Indonesia. E-Jurnal Manajemen Universitas Udayana, 4(5).

Manullang, M. (2004). Dasar-dasar manajemen. Yogyakarta: Gajah Mada University Press.

Pratama, I. G. B., Sinarwati, N. K., \& Darmawan, N. A. S. (2015). Reaksi pasar modal indonesia terhadap peristiwa politik (Event study pada peristiwa pelantikan Joko Widodo sebagai presiden Republik Indonesia ke-7). JIMAT (Jurnal Ilmiah Mahasiswa Akuntansi S1), 3(1).

Rokhman, M. T. N., Didied, P., \& Kiptiyah, S. (2009). Analisis return, abnormal return, aktivitas volume perdagangan dan bid-ask spread saham di seputar pengumuman stock split (Studi pada perusahaan manufaktur di BEJ). Wacana, Jurnal Sosial dan Humaniora, 12(4), 662-677.

Said, E. W. (2017). Tax policy in action: 2016 tax amnesty experience of the Republic of Indonesia. Laws, 6(4), 16.

Sukamulja, S. (2002). What blinks stock market prices? An empirical study from Jakarta Stock Exchange. Jurnal Ekonomi dan Bisnis Indonesia, 17(4), 428-439.

Xu, X. E., \& Wu, C. (1999). The intraday relation between return volatility, transactions, and volume\&. International Review of Economics E Finance, 8(4), 375397. 